\title{
Erratum to: Multivariate quality control of batch processes using STATIS
}

\author{
Danilo Marcondes Filho $^{1} \cdot$ Luiz Paulo Luna Oliveira ${ }^{2}$. Flávio Sanson Fogliatto ${ }^{3}$
}

Published online: 26 May 2016

(C) Springer-Verlag London 2016

Erratum to: Int J Adv Manuf Technol Volume 82, Issue 5, pp 867-875

DOI: 10.1007/s00170-015-7428-0

The name of one author was omitted in the initially published version. The correct list of authors for the article is: Danilo Marcondes Filho, Luiz Paulo Luna Oliveira, Flávio Sanson Fogliatto. The complete list of authors is presented in this paper.

The online version of the original article can be found at http://dx.doi.org/ 10.1007/s00170-015-7428-0.

Danilo Marcondes Filho

marcondes.danilo@gmail.com

1 Department of Statistics, Federal University of Rio Grande do Sul, Porto Alegre, Rio Grande do Sul, Brazil

2 University of Vale do Rio dos Sinos, São Leopoldo, Rio Grande do Sul, Brazil

3 Department of Industrial Engineering, Federal University of Rio Grande do Sul, Porto Alegre, Rio Grande do Sul, Brazil 